\title{
Aromatase expression and regulation in breast and endometrial cancer
}

\author{
Hong Zhao, Ling Zhou, Anna Junjie Shangguan and Serdar E Bulun \\ Division of Reproductive Science in Medicine, Department of Obstetrics and Gynecology, Feinberg \\ School of Medicine, Northwestern University, Chicago, Illinois, USA
}

Correspondence

should be addressed

to $\mathrm{H}$ Zhao

Email

h-zhao@northwestern.edu

\begin{abstract}
Long-term exposure to excess estrogen increases the risk of breast cancer and type 1 endometrial cancer. Most of the estrogen in premenopausal women is synthesized by the ovaries, while extraovarian subcutaneous adipose tissue is the predominant tissue source of estrogen after menopause. Estrogen and its metabolites can cause hyperproliferation and neoplastic transformation of breast and endometrial cells via increased proliferation and DNA damage. Several genetically modified mouse models have been generated to help understand the physiological and pathophysiological roles of aromatase and estrogen in the normal breast and in the development of breast cancers. Aromatase, the key enzyme for estrogen production, is comprised of at least ten partially tissue-selective and alternatively used promoters. These promoters are regulated by distinct signaling pathways to control aromatase expression and estrogen formation via recruitment of various transcription factors to their cis-regulatory elements. A shift in aromatase promoter use from I.4 to I.3/II is responsible for the excess estrogen production seen in fibroblasts surrounding malignant epithelial cells in breast cancers. Targeting these distinct pathways and/or transcription factors to modify aromatase activity may lead to the development of novel therapeutic remedies that inhibit estrogen production in a tissue-specific manner.
\end{abstract}

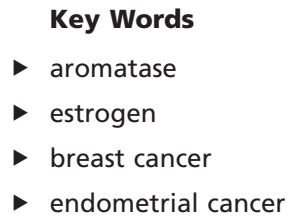

Journal of Molecular

Endocrinology

(2016) 57, R19-R33

\section{Introduction}

Aromatase is the rate-limiting enzyme in estrogen biosynthesis (Simpson \& Santen 2015). The biologically active estrogen, $17 \beta$-estradiol (E2), exerts its actions by binding to its receptors, estrogen receptor- $\alpha$ (ER $\alpha)$ (Lubahn et al. 1993, Couse et al. 1999, Dupont et al. 2000) and estrogen receptor- $\beta$ (Krege et al. 1998). Beyond its essential role in reproductive function (Bulun et al. 2005), estrogen is also involved in vascular biology (O'Lone et al. 2007), lipid and carbohydrate metabolism (Jones et al. 2001), bone mineralization (Nakamura et al. 2007), and cognitive and other brain-related functions (Arevalo et al. 2015). Estrogen also plays an important role in initializing development and further growth of a number of benign and malignant hormone-dependent disorders, including breast and endometrial cancers (Bulun et al. 2005, Cavalieri et al. 2006, Kim et al. 2013, Santen et al. 2015).

Breast cancer is the most common cancer among women in the United States (other than skin cancer). It can be divided into four main molecular subtypes based on the presence or absence of routinely evaluated biological markers: hormone (estrogen or progesterone) receptors (HR+/HR-) and excess levels of human epidermal growth factor receptor 2 (HER2+/HER2-), a protein promoting breast epithelial cell growth (Perou et al. 2000, Cancer Genome Atlas 2012). These four subtypes are luminal A 
(HR+/HER2-, 74\%); luminal B (HR+/HER2+, 10\%); HER2-enriched (HR-/HER2+, 4\%); and triple negative (HR-/HER2-, 12\%) (Anderson et al. 2014, Kohler et al. 2015). The majority of breast cancers (84\%) express estrogen and progesterone receptors, indicating the essential role of estrogen in breast cancer development. Endometrial cancer is the sixth most common cancer in women worldwide and is divided into two types. Type 1 endometrial cancer is thought to be caused by excess estrogen (Jarzabek et al. 2013). Risk factors that affect a woman's estrogen balance play a critical role in this type of endometrial cancer. Type 2 endometrial cancer is not related to estrogen (Morice et al. 2016). This review describes the molecular basis of tissue-specific estrogen production and its role in breast and endometrial cancers. Understanding the mechanisms that control the levels of estrogen in specific tissues may lead to the development of tissue-targeted therapies for estrogen-dependent diseases, such as breast and type 1 endometrial cancer.

\section{Estrogen synthesis and deactivation}

Estrogen is synthesized in the gonads and in several extragonadal organs (Simpson 2003, Bulun et al. 2009). In premenopausal women, six enzymes encoded by five specific genes synthesize estrogen de novo from cholesterol, primarily in the granulosa cells and corpus luteum of ovaries and in the placenta (Simpson 2003). The entry of cytosolic cholesterol into mitochondria initiates estrogen synthesis. In postmenopausal women, estrogen is produced in many extragonadal organs (skin, adipose tissues, liver, heart and brain) (Bulun et al. 2005).

There are three major forms of physiological estrogens in women: estrone (E1), estradiol (E2, or 17 $\beta$-estradiol), and estriol (E3) (Fig. 1) (Cui et al. 2013). E1 is synthesized in skin and adipose tissues from circulating androstenedione of adrenal origin and is the major form of estrogen produced in postmenopausal women (Shozu et al. 2003, Fujisawa \& Castellot 2014). E2 is the most potent estrogen and is the major estrogen product synthesized in the premenopausal ovaries. As in premenopausal women, E2 is also the biologically active estrogen in postmenopausal women even if the circulating E2 levels are low. It is synthesized either by reduction of $\mathrm{E} 1$ in extragonadal sites including skin and adipose tissue or alternatively by direct aromatization of circulating testosterone. E3 is the least potent estrogen and is synthesized in large quantities in the placenta.

Estrogen deactivation occurs via several mechanisms of metabolism and conjugation. The first metabolic pathway of estrogen involves the conversion of $\mathrm{E} 2$ to the less active

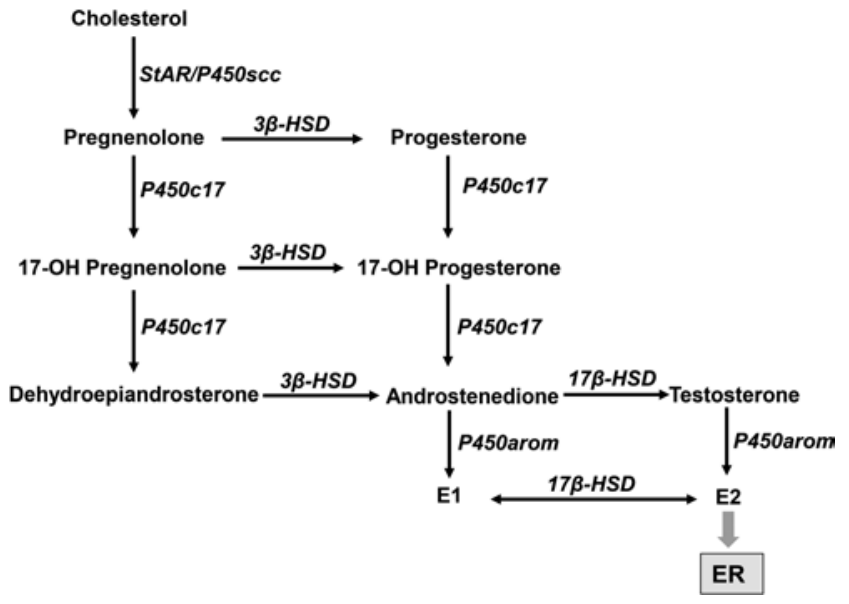

Figure 1

The estrogen biosynthetic pathway involving the conversion of the substrate cholesterol to progestogens, androgens and finally estrogens. The conversion of androgen to estrone (E1) and estradiol (E2) catalyzed by aromatase (P450arom) is the last and key step for production of estrogen, which binds to estrogen receptor (ER). STAR, steroidogenic acute regulatory protein; P450scc, cholesterol side-chain cleavage enzyme; P450c17, steroid 17 $\alpha$-hydroxylase/17,20 lyase; 3 $\beta$-HSD, $3 \beta$-hydroxysteroid dehydrogenase; $17 \beta-H S D, 17 \beta$-hydroxysteroid dehydrogenase.

E1 by $17 \beta$-hydroxysteroid dehydrogenase (17 $\beta$-HSD) and the subsequent sulfation via estrogen sulfotransferase (EST) to form estrone sulfate (E1S), which is a storage form of estrogen that does not interact with ERs. These sulfated E1 can also be reverted to E2 first through deconjugation by steroid sulfatase and then further reduction. The ability of EST to form E1S at physiologic concentrations is critical in regulating the activation of the ER in estrogenresponsive cells (Suzuki et al. 2005, Cos et al. 2014). Conjugation of lipophilic estrogens with sulfate is thus a main pathway for estrogen inactivation in estrogen target tissue (Fujisawa \& Castellot 2014).

In addition to sulfation, $\mathrm{E} 1$ and $\mathrm{E} 2$ can be metabolized by several other pathways. E1 and E2 can be oxidized by cytochrome $\mathrm{P} 450$ enzymes to generate 2- and 4-hydroxycatecholestrogen, which can be further methoxylated by catechol-O-methyltransferase to form 2/4-methoxyestrogen. In addition, E2 and E1 as well as their metabolites can also be conjugated to glucuronic acid via UDP-glucuronosyltransferases. The resulting estrogen glucuronides are completely devoid of biologic activities because they have significantly altered chemical structures that prevent interaction with ERs. The glucuronic acid moiety also increases the aqueous solubility of estrogen and eventually facilitates the excretion of estrogen metabolites in the urine. Thus, while a small amount of estrogen is sulfated and detected in circulation and

Published by Bioscientifica Ltd 
in the bile, the majority of parent estrogens and their metabolites (80-90\%) are glucuronidated and excreted through the urine (Kotov et al. 1999, Guillemette et al. 2004, Tong et al. 2005). The balance between estrogen synthesis and deactivation maintains physiological estrogen homeostasis. Aromatase catalyzes the last and rate-limiting step in E2 synthesis, and aromatase regulation is a major mechanism for controlling estrogen synthesis (Bulun et al. 2005, 2009).

\section{Aromatase: the key estrogen synthase}

The CYP19A1 gene that encodes aromatase protein in humans spans approximately $123 \mathrm{~kb}$ on chromosome $15 \mathrm{q} 21.2$ and consists of a $93 \mathrm{~kb} \mathrm{5'-untranslated} \mathrm{region}$ (UTR), $30 \mathrm{~kb}$ of coding region, and the 3 '-end (Bulun et al. 2005, Boon et al. 2010). The coding region of aromatase contains nine exons (II-X) with the ATG translational start site located in exon II. The $5^{\prime}$-UTR contains a number of alternative untranslated first exons that are regulated by tissue-specific promoters (Fig. 2A). Thus far, ten alternative tissue-specific promoters have been found in humans, including promoters I.1, I.2 and I.2a in placenta; I.4 in adipose tissue and skin; I.5 in fetal tissues; I.f in brain; I.7 in endothelial cells; I.6 in bone; I.3 in adipose tissue; and PII in gonads and adipose tissue (Bulun et al. 2005, 2012). These promoters differentially regulate aromatase expression in gonads, adipose tissue, bone, brain, skin, fetal liver and placenta.

In mice, aromatase is encoded by a single gene named Cyp19a1 that extends to approximately $103 \mathrm{~kb}$ in chromosome 9. The ATG translation start site location (exon II) and the number of coding exons (II-X) are similar to that of the human aromatase gene (Golovine et al. 2003);

\section{A}

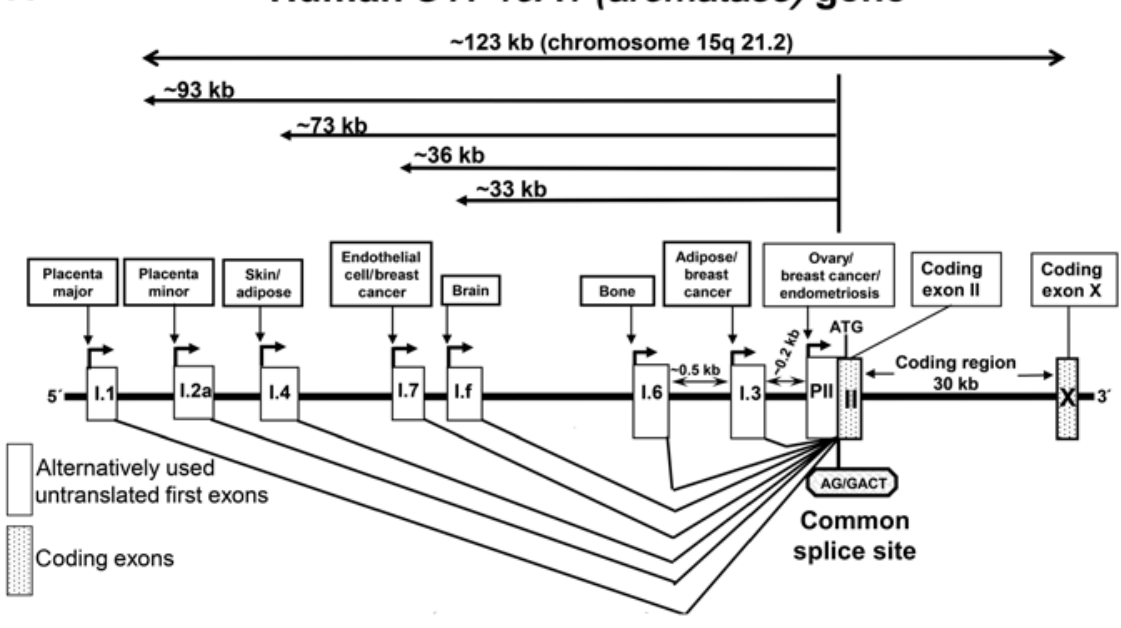

B

\section{Mouse Cyp19A1 (aromatase) gene}

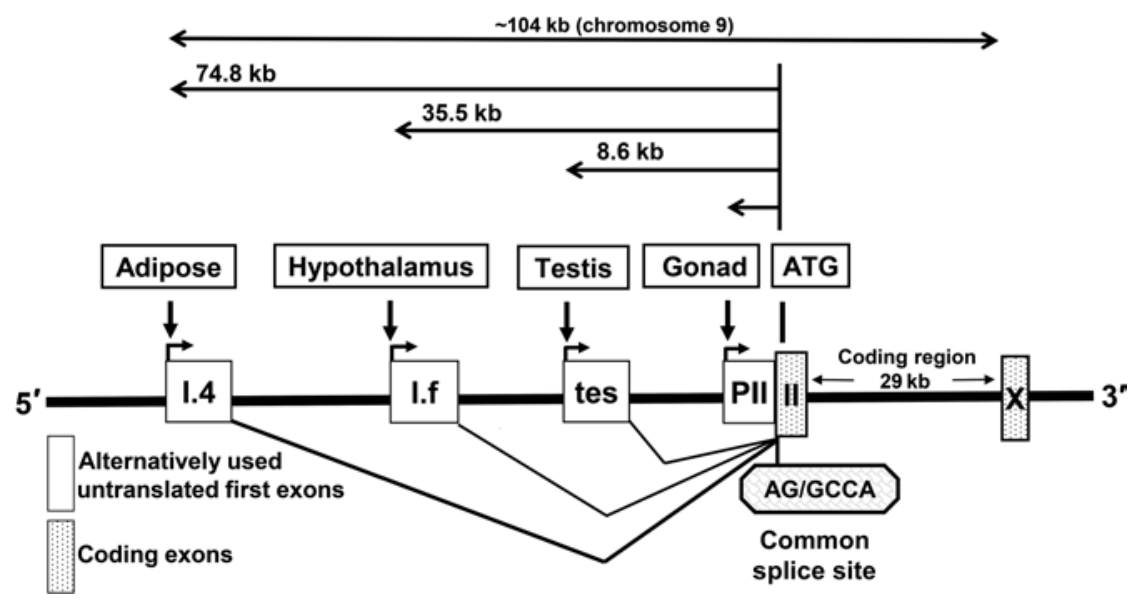

Figure 2

(A) Human aromatase (CYP19A1) and (B) mouse aromatase (Cyp19a1) genes. Expression of the aromatase gene is regulated by the tissue-specific activation of a number of promoters via alternative splicing. Aromatase mRNA species contain promoter-specific 5 '-UTRs. The coding region and encoded protein, however, are identical regardless of the promoter used. http://jme.endocrinology-journals.org
DOI: 10.1530/JME-15-0310
○) 2016 Society for Endocrinology Printed in Great Britain 
however, the lengths of the $5^{\prime}$-UTR and the coding region are 73 and $29 \mathrm{~kb}$, respectively, which are shorter than their human counterparts. Moreover, the aromatase gene in the male mouse contains only four tissue-specific promoters, which are promoters II (gonad), tes (a testis-specific promoter), I.f(brain) andI.4 (gonadalfat) (Fig. 2B). Thefemale mouse contains two tissue-specific promoters (II and I.f) (Zhao et al. 2009, 2012). The mouse gonad-, brain- and fatspecific first exons share 100\%, 93\% and 37\% homology with the human exons PII, I.f and I.4, while the testisspecific first exon is unique to mice (Honda et al. 1994, 1996, Chow et al. 2009, Zhao et al. 2012). In both humans and mice, all of the 5 '-untranslated tissue-specific first exons are spliced onto a common junction located $38 \mathrm{bp}$ upstream of the ATG translational start site. Consequently, the aromatase protein is the same regardless of the splicing pattern (Bulun et al. 2005, Zhao et al. 2009). Mouse aromatase is expressed in fewer tissues than human aromatase; thus, mouse models do not mirror estrogen production in humans. For this reason, we generated a humanized aromatase (Arom ${ }^{\text {hum })}$ mouse model that contains the full human aromatase gene containing the 5'-UTR, the coding region, and the 3 '-end, mimicking human aromatase expression pattern in the mouse model (Zhao et al. 2012). This and other mouse models are described later in this review.

The expression and regulation of the aromatase gene are complicated processes. Tissue-specific aromatase expression depends on three major factors: (1) activation of tissue-specific promoters and transcription of promoter-related first exons, (2) alternative splicing, and (3) the availability of various transcription factors (Bulun et al. 2005, Cui et al. 2013). As described above, the human aromatase gene contains 10 first exons in its 5'-UTR. Each exon 1 is tissue-specific, untranslated and driven by its upstream cognate promoter. Activation of each promoter leads to an alternatively spliced form of mature mRNA with identical coding regions but distinct first untranslated exons. Therefore, the aromatase protein itself is identical across all tissue types regardless of the promoter used. Each promoter is regulated by distinct sets of hormones, cytokines and second messenger signaling pathways, which recruit different transcription factors to regulate tissue-specific aromatase expression and estrogen biosynthesis under physiological or pathological conditions such as breast cancer and endometrial cancer.

\section{Estrogen and breast cancer}

There are three sources of estrogen that support the development and growth of breast cancers
(Simpson 2003, Bulun et al. 2005). First, estrogen synthesized in the ovaries by granulosa cells reaches the breast tissue to act in an endocrine manner. Secondly, estrogen synthesized by aromatase in extraovarian body sites such as subcutaneous adipose tissue and skin also acts on the breast in an endocrine manner. Thirdly, aromatase overexpression within the tumor tissue or in the surrounding stroma increases local levels of estrogen, which acts at the site of synthesis in a paracrine and/or intracrine manner. Tissues involved in estrogen production differ between pre- and postmenopausal women. In postmenopausal breast cancer patients, extraovarian sites and breast cancer tissue are the major estrogen sources, whereas ovaries are the major source of estrogen in premenopausal women with breast cancer. While local estrogen synthesis may be upregulated in postmenopausal benign breast tissue or malignant breast tumors, others have argued that the relative role of circulating pool of estrogens may be more important for breast carcinogenesis (Dunbier et al. 2010, Haynes et al. 2010, Lonning et al. 2011). In this review, we underscore the tumor microenvironment and potential impact of local estrogen produced by aromatase in adipose fibroblasts surrounding the benign or malignant breast epithelial cells.

\section{E2 synthesis in the ovary}

In premenopausal women, circulating E2 is mainly synthesized in the ovaries, which secrete $\mathrm{E} 2$ into the bloodstream for endocrine transport to target tissues to carry out its biological functions. Ovarian follicles are the basic units of female reproductive biology. Each follicle is composed of an oocyte and surrounding granulosa cells. Theca cells form a layer around the granulosa cells as the follicle matures. After ovulation, theca cells luteinize to form the corpus luteum. The theca and granulosa cells collaborate in tissue-specific estrogen synthesis in the ovary (Liu \& Hsueh 1986, Yada et al. 1999). Theca cells lack aromatase, but are able to produce androgen from progesterone, which is then released from theca cells and diffuses into granulosa cells. In contrast, granulosa cells, which lack enzymes for androgen synthesis, express aromatase, which converts androgen from theca cells to estrogen (Cui et al. 2013). Androgen released from adrenal glands also provides a substrate for aromatase to produce estrogen in granulosa cells (Fig. 3A). Circulating E2 levels fluctuate monthly due to the menstrual cycle, with the highest levels immediately before ovulation, intermediate levels in the luteal phase and lowest levels in the

Published by Bioscientifica Ltd. 
A

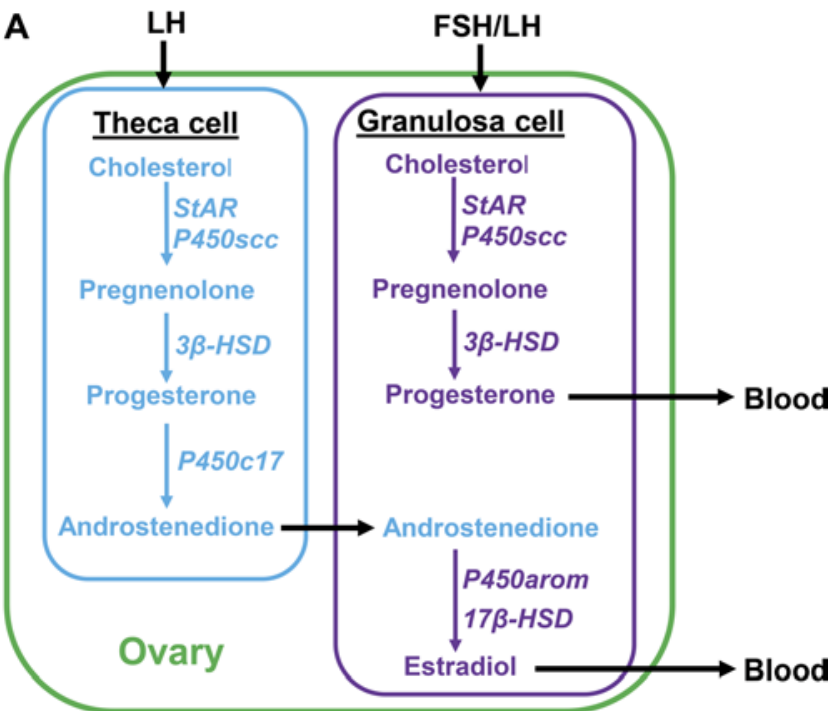

B

FSH

PKA/cAMP

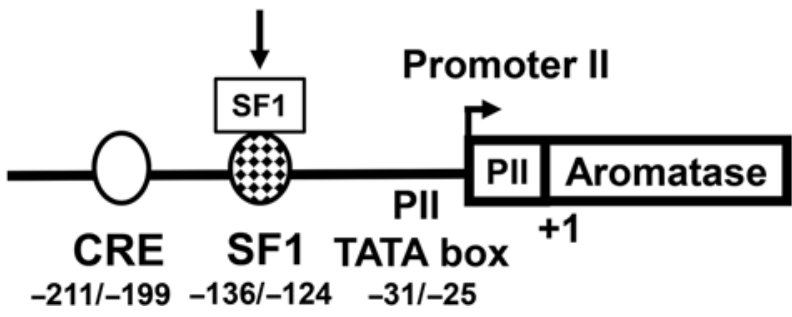

Figure 3

Estrogen synthesis and aromatase promoter II use in the ovary. (A) Gonadotropins (FSH and LH) from the pituitary induce estrogen production in ovary. Progesterone is synthesized from cholesterol via the steroidogenic acute regulatory protein (STAR), the cholesterol side-chain cleavage enzyme (P450scc) and 3 $\beta$-hydroxysteroid dehydrogenase $(3 \beta-H S D)$ in both theca and granulosa cells and is converted to androstenedione via steroid 17 $\alpha$-hydroxylase/17, 20 lyase (P450c17) only in theca cells. Theca cell androstenedione is transported into granulosa cells, where it is converted to estrogen by aromatase (P450arom) and $17 \beta$-hydroxysteroid dehydrogenase (17 $\beta$-HSD). (B) FSH induces aromatase expression via a PKA/cAMP-dependent pathway in ovarian granulosa cells via promoter II. SF-1 mediates this action of FSH.

follicular phase. Over the course of a woman's life, the level of estrogen synthesis is highest during the reproductive years and declines during the transition stage, reaching its lowest levels in the postmenopausal period. Ovarian aromatase expression is mediated primarily by folliclestimulating hormone (FSH) signaling, cyclic AMP (cAMP) production, protein kinase $\mathrm{A}$ (PKA) phosphorylation and activation of the aromatase proximal promoter II (Fig. 3B) (Simpson et al. 1994).

\section{E2 synthesis in skin and adipose tissue}

The estrogen precursor androstenedione is primarily secreted by the adrenal glands in postmenopausal women. Aromatase expression and enzyme activity in skin and subcutaneous adipose fibroblasts give rise to formation of systemically available E1 and, to a lesser extent E2, after menopause. The potential roles of adipose tissue and skin aromatase in human physiology and pathology were initially recognized in the 1960s, specifically the role of adipose tissue-derived estrogen in obese postmenopausal women with breast cancer (MacDonald et al. 1968, Calle et al. 2003). Estrogen formation in skin and fat is positively correlated with increased body weight in postmenopausal women and may be increased by as much as ten-fold in morbidly obese postmenopausal women (Grodin et al. 1973, Hemsell et al. 1974). Later studies in female Arom ${ }^{\text {hum }}$ mice also found that mice fed a high-fat diet gained more weight and had a larger mammary gland mass with elevated total human aromatase mRNA levels (Chen et al. 2012). Overweight or obese postmenopausal women exhibit a three-fold higher risk for developing breast cancer compared with normal-weight postmenopausal women (Ziegler et al. 1996, Morimoto et al. 2002, Gunter et al. 2009), suggesting that estrogen produced in skin and adipose tissue reaches breast tissue via the circulation to stimulate tumor growth (Huang et al. 1997, Hankinson et al. 1998). In addition, surgical ablation of pituitary or adrenal glands was shown to have a palliative effect on breast cancer. E1 or E2 production in adipose tissue uses plasma androstenedione secreted by the adrenal cortex or ovarian testosterone as substrates, suggesting that the palliative effects of adrenalectomy or hypophysectomy may be due to aromatase substrate depletion and a decrease in aromatase-catalyzed adipose tissue estrogen biosynthesis (Santen 1981). The clinical relevance of these findings is underscored by the observed efficacy of aromatase inhibitors in breast cancer treatment in postmenopausal women, which causes a reduction in estrogen biosynthesis in adipose tissue (Brodie et al. 1999a,b). However, for premenopausal women, both prospective cohort and case-control studies consistently report a modest (20-40\%) decreased risk of breast cancer in obese women compared with normal-weight women (Harris et al. 2011, John et al. 2011, Anderson \& Neuhouser 2012, White et al. 2012).

\section{E2 synthesis in normal breast and breast cancer tissues}

In the breast, benign or malignant epithelial cells lie in close contact with endothelial cell-lined capillaries,

Published by Bioscientifica Ltd 
mesenchymal stromal cells (undifferentiated adipose fibroblasts also known as preadipocytes), and lipid-filled mature adipocytes (Bulun et al. 1993). In breast adipose tissue, most aromatase (80-90\%) expression is found in adipose fibroblasts rather than in mature adipocytes (Price et al. 1992). Normal breast adipose tissue maintains low levels of aromatase expression primarily via distal promoter I.4 and uses the proximally located promoters I.3 and II only minimally (Fig. 4). In breast cancer, malignant epithelial cells enrich the population of adipose fibroblasts by secreting large amounts of cytokines such as tumor necrosis factor (TNF) $\alpha$ and interleukin 11 (IL-11) to inhibit differentiation of preadipocytes into mature adipocytes; thus, creating a dense fibroblast layer surrounding malignant epithelial cells in a process called the desmoplastic reaction (Meng et al. 2001). As a result, the total amount of promoter I.4-specific aromatase transcript is increased in breast cancer tissue (Harada 1997). More importantly, malignant breast epithelial cells secrete prostaglandin E2 (PGE2) and other unknown factors to cause aromatase promoter switching from I.4 to the more potent I.3 and II promoters in adipose fibroblasts, leading to increased production of aromatase (Fig. 4) (Zhao et al. 1996a, Zhou et al. 2001, Diaz-Cruz et al. 2005). In addition to breast adipose fibroblasts, breast tumors produce high levels of aromatase, especially via promoter I.3/II (Agarwal et al. 1996). Finally, breast endothelial cells, which proliferate in the pro-angiogenic environment of breast cancer, appear to be a significant site of aromatase expression via promoter I.7 (Fig. 4) (Sebastian et al. 2002). Thus, the prototypical estrogen-dependent breast cancer takes advantage of four promoters (II, I.3, I.7 and I.4) to drive aromatase expression (Fig. 4). The sum of the aromatase mRNA species arising from these four promoters markedly increases total aromatase mRNA levels in breast cancer compared with the normal breast tissue, which almost exclusively uses promoter I.4. Thus, the paracrine interaction between malignant epithelial cells and adipose stromal cells affects adipogenic differentiation and activates a subset of aromatase promoters to drive local estrogen production (Bulun et al. 2005).

\section{Aromatase promoter usage in normal and malignant breast tissues}

Promoter I.4 Aromatase promoter I.4 does not have a TATA or CAAT box upstream of the transcription start site for the untranslated exon I.4 (Fig. 5A) (Zhao et al. 1995a, Chen et al. 2009). The 5'-UTR of exon I.4 contains a putative silencer and several positive cisacting elements, including an AP1 site (-500/-494), an interferon $\gamma$ activation site (GAS, -282/-272), a glucocorticoid response element (GRE, -133/-119), and an Sp1-binding site $(+151 /+158)$, which can recruit and bind the transcriptional factors c-Fos/c-Jun, phosphorylated signal transducer and activator of

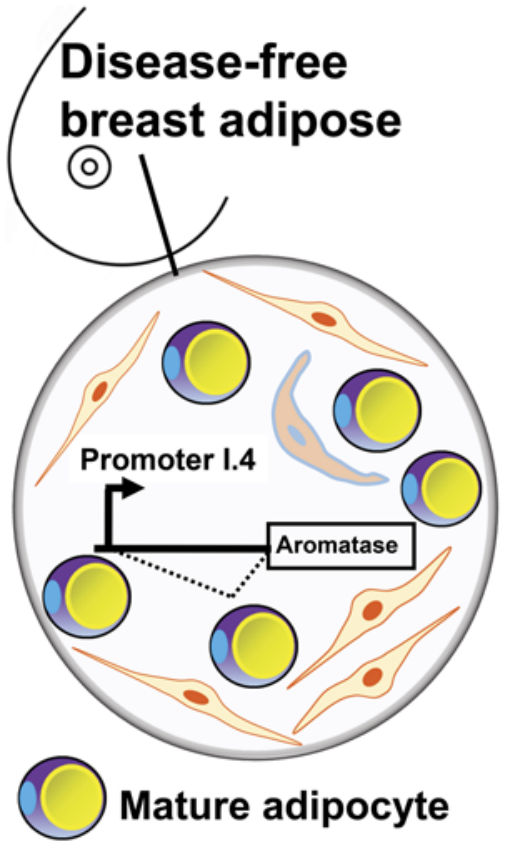

http://jme.endocrinology-journals.org DOI: 10.1530/JME-15-0310

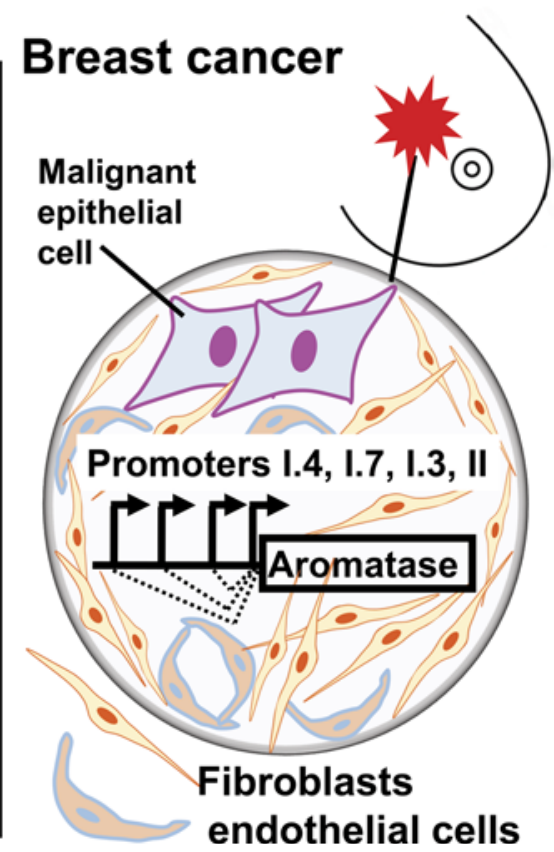

Figure 4

Alternative promoter use for aromatase expression in normal and malignant breast tissues. Normal breast adipose tissue maintains low levels of aromatase expression primarily via promoter I.4. Promoters I.3 and II are used only minimally in normal breast adipose tissue, whereas promoter I.3 and II activity in breast cancer are strikingly increased. Additionally, the endothelial-type promoter 1.7 is upregulated in breast cancer. Thus, the levels of total aromatase mRNA levels from four promoters (II, I.3, I.7 and I.4) in breast cancer tissue are strikingly higher than normal breast tissue.
(C) 2016 Society for Endocrinology Printed in Great Britain
Published by Bioscientifica Ltd 
transcription 3 (phospho-STAT3), glucocorticoid receptor (GR), and Sp1, respectively (Zhao et al. 1995a). Promoter I.4 is predominantly used and minimally activated in normal breast adipose tissue to maintain basal levels of aromatase expression (Bulun et al. 2005). Dexamethasone (DEX) is essential for promoter I.4 activation through stimulation of GR to bind to GRE (-133/-119). We found that TNF $\alpha$ and IL-11 are primarily present in malignant epithelial cells of mastectomy specimens (Meng et al. 2001); however, TNF $\alpha$ and type I cytokines (IL-11, leukemia inhibitory factor (LIF), oncostatin M (OSM), and IL-6) in the presence of DEX stimulate promoter I.4 by different mechanisms. TNF $\alpha+$ DEX together induce expression of c-Fos and c-Jun, which can heterodimerize and bind to AP1 (-500/-494) (Zhao et al. 1996b). By contrast, type I cytokines+DEX stimulate tyrosine phosphorylation of Janus kinase 1 (JAK1), which in turn activate STAT3 through tyrosine phosphorylation. Phospho-STAT3 binds to GAS $(-282 /-272)$ as a part of I.4 activation (Zhao et al. $1995 b)$. Promoter I.4 activation also requires binding of Sp1 protein to its binding site $(+151 /+158)$ (Zhao et al. 1995a). Moreover, TNF $\alpha$ and IL-11 inhibit adipogenic differentiation of undifferentiated fibroblasts, increase the number of aromatase-expressing fibroblasts and increase estrogen production, which in turn prompts IL-11 formation and increases TNF $\alpha$ receptor expression in malignant breast fibroblasts. Thus, promoter I.4derived aromatase expression and estrogen formation are increased in breast cancer specimens, likely due to both cytokine-stimulated promoter I.4 activity and cytokineinduced desmoplastic reaction (Fig. 5A) (Harada 1997).

Promoter I.7 We identified a novel $101 \mathrm{bp}$ untranslated first exon (I.7), a promoter immediately upstream of exon I.7 located approximately $36 \mathrm{~kb}$ upstream of the ATG translation start site of the aromatase gene in breast cancer tissues (Sebastian et al. 2002). Promoter I.7 is a TATA-less promoter with maximal promoter activity in human microvascular endothelial cells. Binding of the transcription factor GATA2 to a specific GATA cisregulatory element in promoter I.7 is critical for aromatase regulation in endothelial cells (Sebastian et al. 2002). The level of aromatase mRNA with exon I.7 is significantly increased in breast cancer tissues and adipose tissue adjacent to tumors (Fig. 5B). Thus, promoter I.7 is a GATA2-regulated endothelial-type promoter of the human aromatase gene and may increase estrogen biosynthesis in vascular endothelial cells in breast cancer. Promoter I.7 activity may also be important for intracrine and paracrine effects of estrogen on blood vessel physiology.
Promoters I.3/II Promoters I.3 and II are located within $215 \mathrm{bp}$ from each other. Because of their proximity, they may share some common cis-regulatory elements (Zhou \& Chen 1999, Zhou et al. 2001). Thus, we will discuss the usage and regulation of these two promoters together. Unlike promoters I.4 and I.7, promoters I.3 and II have TATA boxes that are also $215 \mathrm{bp}$ from each other (Zhou et al. 1997). The 5'-UTR of promoters I.3/II contains many positive cis-acting elements, of which the cAMPresponsive element (CRE, -522/-515), AP1 (-498/-492), CCAAT/enhancer-binding protein (C/EBP, -350/-337), C/EBP (-317/-304), CRE (-292/-285), CRE (-211/-199), and steroidogenic factor-1 (SF-1, $-136 /-124)$ are critical for promoter I.3/II activity. All identified cis-acting elements are located upstream of the promoter II TATA box. For promoter I.3, most of the cis-acting elements are upstream of its TATA box except for CRE $(-211 /-199)$ and SF-1 (-136/-124), which reside downstream of promoter I.3 and inside exon I.3 [24]. These two cis-acting elements are likely involved in regulation of both promoters I.3 and II (Fig. 5C) (Zhou \& Chen 1999, Chen et al. 2001, Zhou et al. 2001, Clyne et al. 2002).

Aromatase promoter switching from I.4 to I.3/II is a major mechanism that mediates increased aromatase expression and local estrogen formation in adipose tissue adjacent to breast cancer and within breast cancer tissue (Agarwal et al. 1996, Utsumi et al. 1996, Zhou et al. 1996). Treatment of undifferentiated adipose fibroblasts with conditioned media from malignant breast epithelia induces aromatase expression (Zhou et al. 2001). This effect can be mimicked by PGE2, which is present in high concentrations in media conditioned with malignant epithelial cells but not in media conditioned with benign breast epithelial cells (Zhou et al. 2001). The biological actions of PGE2 are mediated via protein kinase C (PKC) and the adenylate cyclase/cAMP/PKA pathways (Zhao et al. 1996a, Brueggemeier et al. 2003). In fact, this PGE2 effect can be imitated using a combination of PKA activator (dibutyryl (Bt2) cAMP) and PKC activator (phorbol diacetate (PDA)) (Chen et al. 2007). Other stimulating factors present in breast cancer cell-conditioned medium can activate promoter I.3/II, independent of the PGE2/PKA/PKC pathway. Unknown factor(s) in the conditioned medium markedly induce expression of $\mathrm{C} / \mathrm{EBP} \beta$, which binds to C/EBP $(-317 /-304)$ and stimulates promoter I.3/II. In contrast, C/EBP $(-350 /-337)$ is dispensable for promoter activation (Zhou et al. 2001).

The PGE2/PKA/PKC pathway regulates various transcription factors that bind to different

Published by Bioscientifica Ltd. 

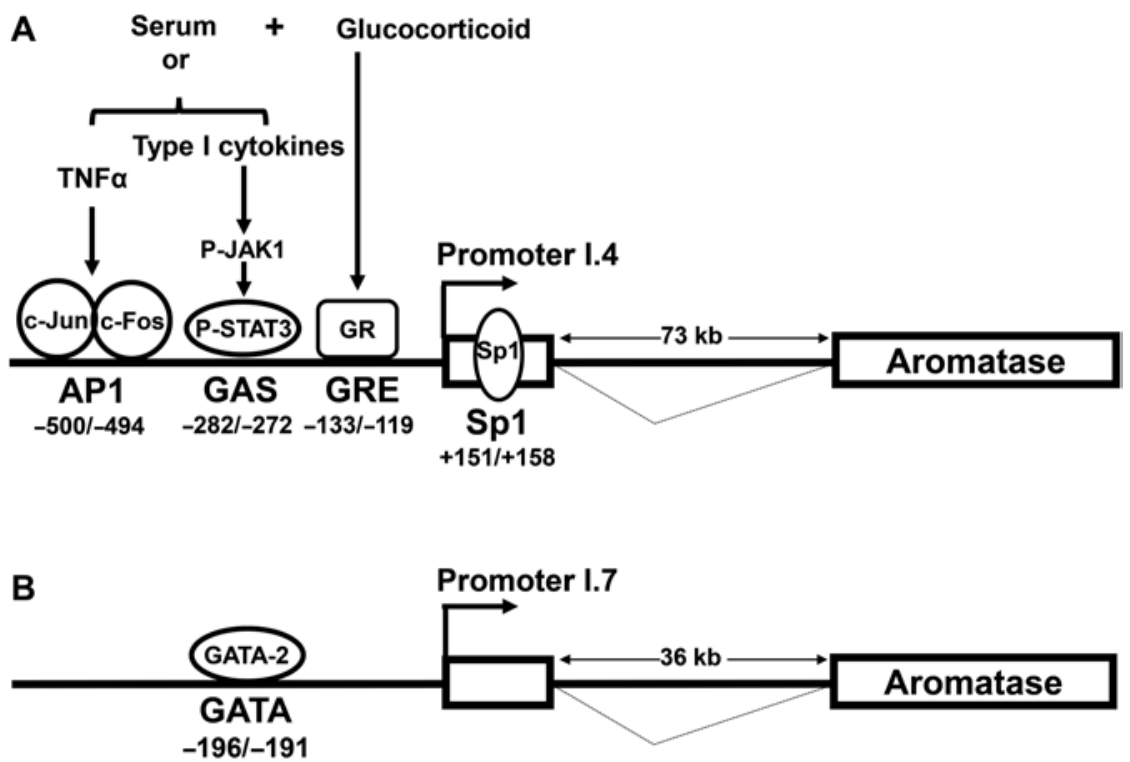

Figure 5

Activation of aromatase promoter I.4 and promoters I.3/II in breast adipose fibroblasts and promoter 1.7 in breast endothelial cells.

(A) Glucocorticoid plus serum stimulates aromatase promoter I.4. Serum can be substituted with TNF $\alpha$ or one of the type I cytokines. Glucocorticoid is obligatory for promoter I.4 stimulation by binding to and activating the glucocorticoid receptor (GR), which interacts with the glucocorticoid response element (GRE) in promoter I.4. TNF $\alpha$ plus glucocorticoid induces expression of c-Jun and

C malignant epithelial cells c-Fos, which heterodimerize and bind to the AP1 site in promoter I.4. Type I cytokines plus glucocorticoid, on the other hand, activate the JAK1/STAT3 pathway, resulting in binding of tyrosine phosphorylated STAT3 to the interferon $\gamma$ activation site (GAS) in promoter I.4. Sp1 protein binding to its binding site is also essential for promoter I.4 stimulation. (B) Promoter I.7 is a TATA-less promoter that directs expression of $29-54 \%$ of aromatase mRNA species in breast cancer. The $-299 /-35$ regulatory region confers maximum basal activity in endothelial cells and contains at least three critical endothelial-type motifs, including Ets, GATA and E47. The binding of GATA2 protein to the $-196 /-191$ bp site is important for baseline promoter activity in endothelial cells. (C) Breast cancer-conditioned medium and PGE2 can activate aromatase PI.3/II via the activation and binding of various transcription factors to their cis-acting elements, driven by distinct signaling pathways. This is accompanied by binding of LRH-1, CREB1, phosphorylated ATF-2 and C-Jun, JunB, JunD, and C/EBP $\beta$ to the promoter I.3/II regulatory region.

cis-acting elements. First, PGE2 strikingly increases both liver receptor homolog-1 (LRH-1) expression and its binding activity to the SF-1-binding site (-136/-124) in the aromatase promoter II in cultured adipose fibroblasts (Clyne et al. 2002). Secondly, CRE-binding protein 1 (CREB1) is a transcription factor directly phosphorylated and activated by PKA, which enhances CREB1 binding to both CRE (-292/-285) and CRE (-211/-199) in promoter I.3/II in breast adipose fibroblasts (Sofi et al. 2003, Chen et al. 2009). CREB1 mRNA levels are significantly higher in breast adipose tissue bearing a tumor than in normal breast adipose tissue, supporting the role of CREB1 in aromatase overexpression in breast cancer (Sofi et al. 2003). Thirdly, PGE2 activation of the p38 and JNK1 MAP kinases via both the PKA and PKC pathways is necessary for stimulation of aromatase expression via promoter I.3/II. Transcription factors ATF2 and c-Jun, which are in vivo substrates of p38 and/or JNK, are also phosphorylated and activated to interact with promoter I.3/II, but at different binding sites (Chen et al. 2007 , 2009, 2011). c-Jun binds to AP1 (-498/-492), CRE (-292/-285) and CRE (-211/-199) (Chen et al. 2011). p38- and/or

Published by Bioscientifica Ltd. 
JNK-phosphorylated ATF-2 may bind to CRE (-292/-285) and/or CRE (-211/-199). Malignant epithelial cellconditioned medium is found to induce phosphorylation of ATF-2 and its binding to the CRE (-211/-199). However, we cannot exclude the possibility that phosphorylated ATF-2 induced by PGE2 does not bind to CRE (-292/-285) in the aromatase promoter II (Zhou et al. 2001, Bulun et al. 2005, Chen et al. 2007). PGE2 also increases the expression of transcription factors JunB and JunD via the PKA/PKC pathway and prompts their binding to AP1 (-498/-492) and CRE (-211/-199). Fourthly, AMP-activated protein kinase (AMPK) plays an important role in energy homeostasis (Brown \& Simpson 2010). Both AMPK and its kinase LKB1 are involved in regulation of aromatase expression in human adipose fibroblasts. Treatment with activators of PKA and PKC, to mimic PGE2, results in nuclear translocation of CREB-regulated transcription coactivator 2 (CRTC2), increased CRTC2 binding to CRE $(-522 /-515)$ in promoter I.3/II, and increased aromatase activity via inhibition of the LKB1/AMPK pathway (Brown et al. 2009, 2010). Leptin treatment can mimic PGE2 action, whereas adiponectin exerts the opposite action (Brown et al. 2009). In summary, malignant breast epithelial cells secrete significant quantities of PGE2 that activates PKA and PKC pathways, which in turn induce aromatase expression by binding various transcriptional factors to the proximal I.3/II promoter region in adjacent adipose fibroblasts (Fig. 5).

\section{Estrogen formation in various transgenic murine models}

Aromatase is only present in gonads, brain and male gonadal fat in mice, whereas it is expressed in many more tissues, including breast tissue, in humans. Thus, wild-type murine models cannot mimic in vivo human aromatase expression patterns and estrogen formation in breast tissue. To circumvent this obstacle, several genetically modified mouse models have been generated to help understand the physiological and pathophysiological roles of aromatase and estrogen in normal breast tissue and the development of breast cancers (Table 1).

Tekmal and coworkers (1996) generated the first aromatase-overexpressing transgenic mouse model (Int5/ aromatase) in 1996, which showed two-fold increased E2 levels in mammary tissue but no increase in circulating E2 levels. The transgene is driven by mouse mammary tumor virus (MMTV) promoter and gives rise to aromatase overexpression in mammary epithelial cells, leading to mammary hyperplasia, dysphasia and fibroadenoma in females and gynecomastia in 3-month-old males in a paracrine and intracrine manner (Tekmal et al. 1996, Kirma et al. 2001, Li \& Rahman 2008). However, overexpressing aromatase in mammary epithelial cells of Int5/aromatase mice cannot mimic human aromatase expression, which occurs predominantly in adipose fibroblasts.

AROM+ mice, bearing the human aromatase gene driven by the human ubiquitin $\mathrm{C}$ promoter, have aromatase expression in many tissues (Li et al. 2001). AROM+ male mice show an extreme imbalance in sex hormone levels with highly elevated serum E2 concentrations and significantly reduced testosterone levels compared with wild-type littermates. In addition, serum levels of prolactin and corticosterone are increased and serum FSH levels are decreased (Li et al. 2001). AROM+ mice exhibit a low incidence of hyperplasia (10\%) in females of advanced age (15 months) and gynecomastia in males at young age (20 days) (Li et al. 2001, 2002, Li \& Rahman 2008). The aromatase-expressing cell types in mammary tissue are unknown. As the AROM+ mice have abnormal levels of several hormones, these mice cannot be used to pinpoint estrogen-specific biological functions. Moreover, AROM+ female mice with a milder phenotype indicate that breast in situ estrogen, but not systemic estrogen, may be more important for breast cancer development.

A doxycycline-inducible, breast epithelial cell-specific aromatase-expressing transgenic mouse (Arom) model was developed to investigate the molecular pathways involved in the development of mammary preneoplasia and carcinoma (Diaz-Cruz et al. 2011). These Arom mice exhibit increased preneoplasia and carcinoma. Increased prevalence of pathologic changes in Arom mouse mammary tissue correlate with increased cyclin $\mathrm{E}$ and cyclin-dependent kinase 2 expression. Arom mice have significantly higher aromatase activity in mammary tissue while the serum estrogen levels are not different, indicating that estrogen produced in epithelial cells induce breast cancer development in a paracrine and intracrine manner. Again, overexpressing aromatase in mammary epithelial cells does not mimic human aromatase expression, which occurs predominantly in adipose fibroblasts.

We generated a transgenic humanized aromatase (Aromhum) mouse line containing a single copy of the human aromatase gene to study the link between aromatase expression in mammary adipose tissue and breast pathology (Chen et al. 2012, Zhao et al. 2012). Aromhum mice express human aromatase, driven by the proximal human promoters II and I.3 and the distal promoter I.4, in breast adipose fibroblasts and myoepithelial cells. Estrogen levels in the breast tissue of Arom ${ }^{\text {hum }}$ mice are higher than in wild-type mice, whereas circulating levels

Published by Bioscientifica Ltd 
Table 1 Comparison of the various aromatase transgenic mouse models.

\begin{tabular}{|c|c|c|}
\hline Mouse models & Promoter used & Serum E2 levels \\
\hline Int5/aromatase & MMTV (epithelial cells) & No change \\
\hline Arom + & $\begin{array}{l}\text { Ubiquitin C (ubiquitous } \\
\text { expression) }\end{array}$ & $\begin{array}{l}\sim 10 \text { - to } 22 \text {-fold } \\
\text { increase }\end{array}$ \\
\hline Arom & MMTV (epithelial cells) & Unknown \\
\hline Arom ${ }^{\text {hum }}$ & $\begin{array}{l}\text { Native (myoepithelial cells } \\
\text { and adipose fibroblasts) }\end{array}$ & No change \\
\hline
\end{tabular}

\section{Mammary E2 levels \\ two-fold increase}

Unknown

No change -two-fold increase

\begin{tabular}{l} 
Mammary phenotypes \\
\hline Hyperplasia, dysphasia and \\
fibroadenoma in females and \\
gynecomastia in males \\
Hyperplasia in females and \\
gynecomastia in males \\
Preneoplasia and carcinoma \\
Hyperplasia and carcinoma in females \\
and gynecomastia in males
\end{tabular}

are similar. Arom ${ }^{\text {hum }}$ mice exhibit accelerated mammary duct elongation (puberty), and an increased incidence of lobuloalveolar breast hyperplasia (middle age) and mammary tumors (aging mice, our unpublished data). Hyperplastic epithelial cells have remarkably increased proliferative activity. With this model, we demonstrated that the human aromatase gene can be expressed via its native promoters in a wide variety of mouse tissues and in a distribution pattern nearly identical to that of humans. Locally increased tissue levels, but not circulating levels, of estrogen appeared to exert hyperplastic effects on the mammary gland in a paracrine manner. This novel mouse model will be valuable for developing tissue-specific aromatase inhibition strategies.

In summary, studies with these animal models have demonstrated that increased estrogen synthesis in mammary epithelial cells, adipose fibroblasts or in multiple organs with strikingly higher systemic estrogen leads to benign mammary hyperplasia and fibroadenoma in females and gynecomastia in males. Moreover, local mammary aromatase expression and estrogen formation increase breast cancer risk in a paracrine and/or intracrine manner. However, none of these murine models reveals the role of only increased circulating E2 in breast cancer development.

\section{Estrogen and endometrial cancer}

Endometrial cancer is the most common gynecological malignancy in US women (Morice et al. 2016). Type 1 endometrial cancer is the most common type, thought to be caused by excess estrogen, usually not very aggressive, and slow to spread to other tissues; however, type 2 endometrial cancer is not related to estrogen stimulation and usually presents as a higher-grade cancer with a poorer prognosis (Bokhman 1983, Rizner 2013). Type 1 endometrial adenocarcinoma occurs in the context of chronic exposure to excess estrogen (endogenous and exogenous) with insufficient opposing progesterone.
High levels of endogenous estrogen arise as a consequence of various disease states, including anovulation, polycystic ovarian syndrome and obesity (Creasman 1997, Morice et al. 2016). Exogenous estrogen-only hormone replacement therapy (HRT) can promote the development of endometrial cancer compared with an estrogen plus progestin regimen (Beresford et al. 1997, Rossouw et al. 2002). With this regimen, progestin serves as an estrogen antagonist in the endometrium. Progestins have been used clinically to treat endometrial neoplasias. Tamoxifen exerts anti-estrogen effects in breast but acts as an E2 agonist in the uterus. Thus, treatment of breast cancer with tamoxifen increases the risk of developing endometrial cancer (Swerdlow et al. 2005, Chen et al. 2014). Although the pro-proliferative (Siiteri 1978, Key \& Pike 1988) and DNA damaging (Roy \& Liehr 1999, Shibutani et al. 2000) effects of estrogen and its metabolites lead to the hyperproliferation and transformation of cells, the underlying mechanisms involved in endometrial carcinogenesis from chronic estrogen exposure are unclear.

Three major sites in the body produce estrogen in women with endometrial cancers (Bulun et al. 2005, Bulun 2009). First, E2 secreted by the ovary reaches endometrial cancer tissue through the systemic circulation. Secondly, aromatase in adipose tissue and skin catalyzes the conversion of circulating androstenedione to E1 that is subsequently converted to E2, and both E1 and E2 can enter the circulation and reach sites of endometrial cancer. Finally, the third source is estrogen that is synthesized locally in endometrial cancer tissues.

As indicated above, a cascade of steroidogenic genes is needed to synthesize estrogen from cholesterol, including aromatase - the key enzyme for the last step of estrogen formation (Bulun et al. 2005). In premenopausal women, ovarian estrogen is the main source of estrogen for endometrial tissue or endometrial cancer, as disease-free endometrium lacks aromatase and thus does not produce estrogen locally (Bulun 2009). Although aromatase mRNA is absent in tissue homogenates of both proliferative-phase

Published by Bioscientifica Ltd. 
endometrium and secretory-phase endometrium, it is present in first-trimester decidua (Gibson et al. 2013). During the luteal phase, the progesterone-dependent $17 \beta-H S D 2$ enzyme catalyzes the conversion of the biologically active E2 to the less estrogenic E1, which partially inhibits systemic estrogen action.

Quantitative PCR with high cycle numbers amplifies aromatase mRNA in endometrial biopsies, but we cannot detect aromatase enzyme activity in cultured endometrial stromal cells from disease-free women (Noble et al. 1996). Aromatase activity or mRNA cannot be induced by PGE2 or cAMP analogs in stromal cells from diseasefree women, which is the main molecular mechanism responsible for increased expression of steroidogenic genes in stromal cells from diseased tissue such as endometriosis (Noble et al. 1996, Bulun et al. 2001, Sebastian \& Bulun 2001, Sebastian et al. 2002). In postmenopausal women, extraovarian adipose tissues and skin may be the main sites of estrogen formation, which exerts biological effects on the endometrium or endometrial cancer tissues in an endocrine manner. The local concentration of E2 in endometrial cancer tissues is also reported to be higher than in blood or in the endometrium of cancer-free women (Nagasako et al. 1988, Potischman et al. 1996, Sherman et al. 1997, Berstein et al. 2002). It is, therefore, conceivable that endometrial cancer synthesizes E2 in situ, which then contributes to cancer development. One study demonstrated significant conversion of androstenedione to E1 in endometrial cancer tissue (Yamamoto et al. 1993). Aromatase protein and mRNA are detected in endometrial cancer using immunohistochemistry and RT-PCR, whereas aromatase expression is low or undetectable in endometrial hyperplasia (a precursor lesion of endometrial cancer) (Bulun et al. 1994, Watanabe et al. 1995). Immunoreactive aromatase is also found in malignant epithelial, endometrial stromal and myometrial cells. These observations suggest that intratumoral aromatase may play a role in the pathology of endometrial cancer. Taken together, as supported by aromatase availability, tissues from ovaries, skin, adipose and endometrial cancer are the major sources of estrogen for premenopausal endometrial cancers; extraovarian skin and adipose tissue and endometrial cancer tissue are predominant sites of estrogen formation in postmenopausal endometrial cancers.

\section{Conclusion and future directions}

Estrogen plays a critical role in tumor formation and growth, and provides a therapeutic target for the prevention and treatment of breast and endometrial cancers. Aromatase is the rate-limiting enzyme in estrogen biosynthesis, with expression driven by multiple tissue-specific, untranslated and alternative promoters. Aromatase inhibitors have been used successfully to treat breast cancer in postmenopausal women but they reduce aromatase activity indiscriminately throughout the body, resulting in severe estrogen deprivation and major side effects such as bone loss and abnormal lipid metabolism. The shift of aromatase promoter usage in malignant tissues is a major mechanism driving abnormal aromatase overexpression and estrogen excess. Targeting these partially tissue-selective promoters in breast and endometrial cancers provides a potential opportunity to inhibit aromatase activity specifically in breast and endometrial tissue without the common side effects of aromatase inhibitors in other organs, such as the bone. Future basic research will focus on the mechanism of aromatase gene regulation in breast and endometrial cancer to identify ideal drug targets for developing selective aromatase modulators or inhibitors and for blocking estrogen production in targeted tissues.

Declaration of interest

The authors declare that there is no conflict of interest that could be perceived as prejudicing the impartiality of this review.

Funding

This work was supported by the Avon Foundation for Women.

\section{References}

Agarwal VR, Bulun SE, Leitch M, Rohrich R \& Simpson ER 1996 Use of alternative promoters to express the aromatase cytochrome $\mathrm{P} 450$ (CYP19) gene in breast adipose tissues of cancer-free and breast cancer patients. Journal of Clinical Endocrinology and Metabolism $\mathbf{8 1}$ 3843-3849.

Anderson GL \& Neuhouser ML 2012 Obesity and the risk for premenopausal and postmenopausal breast cancer. Cancer Prevention Research 5 515-521. (doi:10.1158/1940-6207.CAPR-12-0091)

Anderson WF, Rosenberg PS \& Katki HA 2014 Tracking and evaluating molecular tumor markers with cancer registry data: HER2 and breast cancer. Journal of National Cancer Institute 106 dju093. (doi:10.1093/jnci/dju093)

Arevalo MA, Azcoitia I \& Garcia-Segura LM 2015 The neuroprotective actions of oestradiol and oestrogen receptors. Nature Review Neuroscience 16 17-29. (doi:10.1038/nrn3856)

Beresford SA, Weiss NS, Voigt LF \& McKnight B 1997 Risk of endometrial cancer in relation to use of oestrogen combined with cyclic progestagen therapy in postmenopausal women. Lancet 349 458-461. (doi:10.1016/S0140-6736(96)07365-5)

Berstein L, Maximov S, Gershfeld E, Meshkova I, Gamajunova V, Tsyrlina E, Larionov A, Kovalevskij A \& Vasilyev D 2002 Neoadjuvant therapy of endometrial cancer with the aromatase 
inhibitor letrozole: endocrine and clinical effects. European Journal of Obstetrics \& Gynecology and Reproductive Biology 105 161-165.

Bokhman JV 1983 Two pathogenetic types of endometrial carcinoma. Gynecologic Oncology 15 10-17. (doi:10.1016/0090-8258(83)90111-7)

Boon WC, Chow JD \& Simpson ER 2010 The multiple roles of estrogens and the enzyme aromatase. Progress Brain Research 181 209-232. (doi:10.1016/S0079-6123(08)81012-6)

Brodie A, Lu Q, Liu Y \& Long B 1999a Aromatase inhibitors and their antitumor effects in model systems. Endocrine-Related Cancer 6 205-210.

Brodie A, Lu Q \& Long B 1999b Aromatase and its inhibitors. Journal of Steroid Biochemistry and Molecular Biology 69 205-210.

Brown KA \& Simpson ER 2010 Obesity and breast cancer: progress to understanding the relationship. Cancer Research 70 4-7. (doi:10.1158/0008-5472.CAN-09-2257)

Brown KA, McInnes KJ, Hunger NI, Oakhill JS, Steinberg GR \& Simpson ER 2009 Subcellular localization of cyclic AMP-responsive element binding protein-regulated transcription coactivator 2 provides a link between obesity and breast cancer in postmenopausal women. Cancer Research 69 5392-5399. (doi:10.1158/0008-5472.CAN-09-0108)

Brown KA, Hunger NI, Docanto M \& Simpson ER 2010 Metformin inhibits aromatase expression in human breast adipose stromal cells via stimulation of AMP-activated protein kinase. Breast Cancer Research Treatment 123 591-596. (doi:10.1007/s10549-010-0834-y)

Brueggemeier RW, Richards JA \& Petrel TA 2003 Aromatase and cyclooxygenases: enzymes in breast cancer. Journal of Steroid Biochemistry and Molecular Biology 86 501-507. (doi:10.1016/S0960-0760(03)00380-7)

Bulun SE 2009 Endometriosis. New England Journal of Medicine 360 268-279. (doi:10.1056/NEJMra0804690)

Bulun SE, Price TM, Aitken J, Mahendroo MS \& Simpson ER 1993 A link between breast cancer and local estrogen biosynthesis suggested by quantification of breast adipose tissue aromatase cytochrome P450 transcripts using competitive polymerase chain reaction after reverse transcription. Journal of Clinical Endocrinology and Metabolism $\mathbf{7 7}$ $1622-1628$.

Bulun SE, Economos K, Miller D \& Simpson ER 1994 CYP19 (aromatase cytochrome P450) gene expression in human malignant endometrial tumors. Journal of Clinical Endocrinology and Metabolism 79 1831-1834.

Bulun SE, Yang S, Fang Z, Gurates B, Tamura M, Zhou J \& Sebastian S 2001 Role of aromatase in endometrial disease. Journal of Steroid Biochemistry and Molecular Biology 79 19-25. (doi:10.1016/S09600760(01)00134-0)

Bulun SE, Lin Z, Imir G, Amin S, Demura M, Yilmaz B, Martin R, Utsunomiya H, Thung S, Gurates B, et al. 2005 Regulation of aromatase expression in estrogen-responsive breast and uterine disease: from bench to treatment. Pharmacological Reviews $\mathbf{5 7}$ 359-383. (doi:10.1124/pr.57.3.6)

Bulun SE, Lin Z, Zhao H, Lu M, Amin S, Reierstad S \& Chen D 2009 Regulation of aromatase expression in breast cancer tissue. Annals of the New York Academy of Sciences 1155 121-131. (doi:10.1111/j.1749-6632.2009.03705.x)

Bulun SE, Chen D, Moy I, Brooks DC \& Zhao H 2012 Aromatase, breast cancer and obesity: a complex interaction. Trends in Endocrinology and Metabolism 23 83-89. (doi:10.1016/j.tem.2011.10.003)

Calle EE, Rodriguez C, Walker-Thurmond K \& Thun MJ 2003 Overweight, obesity, and mortality from cancer in a prospectively studied cohort of U.S. adults. New England Journal of Medicine 348 1625-1638.

Cancer Genome Atlas Network 2012 Comprehensive molecular portraits of human breast tumours. Nature 490 61-70. (doi:10.1038/nature11412)

Cavalieri E, Chakravarti D, Guttenplan J, Hart E, Ingle J, Jankowiak R, Muti P, Rogan E, Russo J, Santen R, et al. 2006 Catechol estrogen quinones as initiators of breast and other human cancers: implications for biomarkers of susceptibility and cancer prevention. Biochimica et Biophysica Acta 1766 63-78.

Chen S, Zhou D, Yang C, Okubo T, Kinoshita Y, Yu B, Kao YC \& Itoh T 2001 Modulation of aromatase expression in human breast tissue.
Journal of Steroid Biochemistry and Molecular Biology 79 35-40. (doi:10.1016/S0960-0760(01)00132-7)

Chen D, Reierstad S, Lin Z, Lu M, Brooks C, Li N, Innes J \& Bulun SE 2007 Prostaglandin E(2) induces breast cancer related aromatase promoters via activation of p38 and c-Jun $\mathrm{NH}(2)$-terminal kinase in adipose fibroblasts. Cancer Research 67 8914-8922. (doi:10.1158/0008-5472.CAN-06-4751)

Chen D, Reierstad S, Lu M, Lin Z, Ishikawa H \& Bulun SE 2009 Regulation of breast cancer-associated aromatase promoters. Cancer Letters 273 15-27. (doi:10.1016/j.canlet.2008.05.038)

Chen D, Reierstad S, Fang F \& Bulun SE 2011 JunD and JunB integrate prostaglandin E2 activation of breast cancer-associated proximal aromatase promoters. Molecular Endocrinology 25 767-775. (doi:10.1210/me.2010-0368)

Chen D, Zhao H, Coon JS IV, Ono M, Pearson EK \& Bulun SE 2012 Weight gain increases human aromatase expression in mammary gland. Molecular and Cellular Endocrinology 355 114-120. (doi:10.1016/j.mce.2012.01.027)

Chen JY, Kuo SJ, Liaw YP, Avital I, Stojadinovic A, Man YG, Mannion C, Wang J, Chou MC, Tsai HD, et al. 2014 Endometrial cancer incidence in breast cancer patients correlating with age and duration of tamoxifen use: a population based study. Journal of Cancer $\mathbf{5}$ 151-155. (doi:10.7150/jca.8412)

Chow JD, Simpson ER \& Boon WC 2009 Alternative 5'-untranslated first exons of the mouse Cyp19A1 (aromatase) gene. Journal of Steroid Biochemistry and Molecular Biology 115 115-125. (doi:10.1016/j. jsbmb.2009.03.010)

Clyne CD, Speed CJ, Zhou J \& Simpson ER 2002 Liver receptor homologue-1 (LRH-1) regulates expression of aromatase in preadipocytes. Journal of Biological Chemistry 277 20591-20597. (doi:10.1074/jbc.M201117200)

Cos S, Alvarez-Garcia V, Gonzalez A, Alonso-Gonzalez C \& MartinezCampa C 2014 Melatonin modulation of crosstalk among malignant epithelial, endothelial and adipose cells in breast cancer (review). Oncology Letters 8 487-492.

Couse JF, Hewitt SC, Bunch DO, Sar M, Walker VR, Davis BJ \& Korach KS 1999 Postnatal sex reversal of the ovaries in mice lacking estrogen receptors alpha and beta. Science 286 2328-2331. (doi:10.1126/science.286.5448.2328)

Creasman WT 1997 Endometrial cancer: incidence, prognostic factors, diagnosis, and treatment. Seminars in Oncology 24 S1-140-S141-150.

Cui J, Shen Y \& Li R 2013 Estrogen synthesis and signaling pathways during aging: from periphery to brain. Trends in Molecular Medicine 19 197-209. (doi:10.1016/j.molmed.2012.12.007)

Diaz-Cruz ES, Shapiro CL \& Brueggemeier RW 2005 Cyclooxygenase inhibitors suppress aromatase expression and activity in breast cancer cells. Journal of Clinical Endocrinology and Metabolism 90 2563-2570. (doi:10.1210/jc.2004-2029)

Diaz-Cruz ES, Sugimoto Y, Gallicano GI, Brueggemeier RW \& Furth PA 2011 Comparison of increased aromatase versus ERalpha in the generation of mammary hyperplasia and cancer. Cancer Research $\mathbf{7 1}$ 5477-5487. (doi:10.1158/0008-5472.CAN-10-4652)

Dunbier AK, Anderson H, Ghazoui Z, Folkerd EJ, A'Hern R, Crowder RJ, Hoog J, Smith IE, Osin P, Nerurkar A, et al. 2010 Relationship between plasma estradiol levels and estrogen-responsive gene expression in estrogen receptor-positive breast cancer in postmenopausal women. Journal of Clinical Oncology 28 1161-1167. (doi:10.1200/JCO.2009.23.9616)

Dupont S, Krust A, Gansmuller A, Dierich A, Chambon P \& Mark M 2000 Effect of single and compound knockouts of estrogen receptors alpha (ERalpha) and beta (ERbeta) on mouse reproductive phenotypes. Development 127 4277-4291.

Fujisawa C \& Castellot JJ Jr 2014 Matrix production and remodeling as therapeutic targets for uterine leiomyoma. Journal of Cell Communication and Signaling 8 179-194. (doi:10.1007/s12079-014-0234-x) http://jme.endocrinology-journals.org

DOI: 10.1530/JME-15-0310
() 2016 Society for Endocrinology Printed in Great Britain
Published by Bioscientifica Ltd 
Gibson DA, McInnes KJ, Critchley HO \& Saunders PT 2013 Endometrial intracrinology - generation of an estrogen-dominated microenvironment in the secretory phase of women. Journal of Clinical Endocrinology and Metabolism 98 E1802-E1806. (doi:10.1210/ jc.2013-2140)

Golovine K, Schwerin M \& Vanselow J 2003 Three different promoters control expression of the aromatase cytochrome p450 gene (cyp19) in mouse gonads and brain. Biology of Reproduction 68 978-984. (doi:10.1095/biolreprod.102.008037)

Grodin JM, Siiteri PK \& MacDonald PC 1973 Source of estrogen production in postmenopausal women. Journal of Clinical Endocrinology and Metabolsim 36 207-214. (doi:10.1210/ jcem-36-2-207)

Guillemette C, Belanger A \& Lepine J 2004 Metabolic inactivation of estrogens in breast tissue by UDP-glucuronosyltransferase enzymes: an overview. Breast Cancer Research 6 246-254. (doi:10.1186/bcr936)

Gunter MJ, Hoover DR, Yu H, Wassertheil-Smoller S, Rohan TE, Manson JE, Li J, Ho GY, Xue X, Anderson GL, et al. 2009 Insulin, insulin-like growth factor-I, and risk of breast cancer in postmenopausal women. Journal of National Cancer Institute 101 48-60. (doi:10.1093/jnci/djn415)

Hankinson SE, Willett WC, Manson JE, Colditz GA, Hunter DJ, Spiegelman D, Barbieri RL \& Speizer FE 1998 Plasma sex steroid hormone levels and risk of breast cancer in postmenopausal women. Journal of National Cancer Institute 90 1292-1299. (doi:10.1093/ jnci/90.17.1292)

Harada N 1997 Aberrant expression of aromatase in breast cancer tissues. Journal of Steroid Biochemistry and Molecular Biology 61 175-184. (doi:10.1016/S0960-0760(97)80010-6)

Harris HR, Willett WC, Terry KL \& Michels KB 2011 Body fat distribution and risk of premenopausal breast cancer in the Nurses' Health Study II. Journal of National Cancer Institute 103 273-278. (doi:10.1093/jnci/djq500)

Haynes BP, Straume AH, Geisler J, A'Hern R, Helle H, Smith IE, Lonning PE \& Dowsett M 2010 Intratumoral estrogen disposition in breast cancer. Clinical Cancer Research 16 1790-1801. (doi:10.1158/1078-0432.CCR-09-2481)

Hemsell DL, Grodin JM, Brenner PF, Siiteri PK \& MacDonald PC 1974 Plasma precursors of estrogen. II. Correlation of the extent of conversion of plasma androstenedione to estrone with age. Journal of Clinical Endocrinology and Metabolism 38 476-479. (doi:10.1210/jcem38-3-476)

Honda S, Harada N \& Takagi Y 1994 Novel exon 1 of the aromatase gene specific for aromatase transcripts in human brain. Biochemical and Biophysics Research Communications 198 1153-1160. (doi:10.1006/bbrc.1994.1163)

Honda S, Harada N \& Takagi Y 1996 The alternative exons 1 of the mouse aromatase cytochrome P-450 gene. Biochimica et Biophysica Acta 1305 145-150. (doi:10.1016/0167-4781(95)00200-6)

Huang Z, Hankinson SE, Colditz GA, Stampfer MJ, Hunter DJ, Manson JE, Hennekens CH, Rosner B, Speizer FE \& Willett WC 1997 Dual effects of weight and weight gain on breast cancer risk. JAMA 278 1407-1411. (doi:10.1001/jama.1997.03550170037029)

Jarzabek K, Koda M, Walentowicz-Sadlecka M, Grabiec M, Laudanski P \& Wolczynski S 2013 Altered expression of ERs, aromatase, and COX2 connected to estrogen action in type 1 endometrial cancer biology. Tumour Biology 34 4007-4016. (doi:10.1007/s13277-013-0991-9)

John EM, Sangaramoorthy M, Phipps AI, Koo J \& Horn-Ross PL 2011 Adult body size, hormone receptor status, and premenopausal breast cancer risk in a multiethnic population: the San Francisco Bay Area breast cancer study. American Journal of Epidemiology 173 201-216. (doi:10.1093/aje/kwq345)

Jones ME, Thorburn AW, Britt KL, Hewitt KN, Misso ML, Wreford NG, Proietto J, Oz OK, Leury BJ, Robertson KM, et al. 2001 Aromatasedeficient (ArKO) mice accumulate excess adipose tissue. Journal of
Steroid Biochemistry and Molecular Biology 79 3-9. (doi:10.1016/S09600760(01)00136-4)

Key TJ \& Pike MC 1988 The dose-effect relationship between 'unopposed' oestrogens and endometrial mitotic rate: its central role in explaining and predicting endometrial cancer risk. British Journal of Cancer 57 205-212. (doi:10.1038/bjc.1988.44)

Kim JJ, Kurita T \& Bulun SE 2013 Progesterone action in endometrial cancer, endometriosis, uterine fibroids, and breast cancer. Endocrine Reviews 34 130-162. (doi:10.1210/er.2012-1043)

Kirma N, Gill K, Mandava U \& Tekmal RR 2001 Overexpression of aromatase leads to hyperplasia and changes in the expression of genes involved in apoptosis, cell cycle, growth, and tumor suppressor functions in the mammary glands of transgenic mice. Cancer Research 61 1910-1918.

Kohler BA, Sherman RL, Howlader N, Jemal A, Ryerson AB, Henry KA, Boscoe FP, Cronin KA, Lake A, Noone AM, et al. 2015 Annual report to the nation on the status of cancer, 1975-2011, featuring incidence of breast cancer subtypes by race/ethnicity, poverty, and state. Journal of National Cancer Institute 107 djv048. (doi:10.1093/jnci/djv048)

Kotov A, Falany JL, Wang J \& Falany CN 1999 Regulation of estrogen activity by sulfation in human Ishikawa endometrial adenocarcinoma cells. Journal of Steroid Biochemistry and Molecular Biology 68 137-144. (doi:10.1016/S0960-0760(99)00022-9)

Krege JH, Hodgin JB, Couse JF, Enmark E, Warner M, Mahler JF, Sar M, Korach KS, Gustafsson JA \& Smithies O 1998 Generation and reproductive phenotypes of mice lacking estrogen receptor beta. PNAS 95 15677-15682. (doi:10.1073/pnas.95.26.15677)

Li X \& Rahman N 2008 Impact of androgen/estrogen ratio: lessons learned from the aromatase over-expression mice. General and Comparative Endocrinology 159 1-9. (doi:10.1016/j.ygcen.2008.07.025)

Li X, Nokkala E, Yan W, Streng T, Saarinen N, Warri A, Huhtaniemi I, Santti R, Makela S \& Poutanen M 2001 Altered structure and function of reproductive organs in transgenic male mice overexpressing human aromatase. Endocrinology 142 2435-2442.

Li X, Warri A, Makela S, Ahonen T, Streng T, Santti R \& Poutanen M 2002 Mammary gland development in transgenic male mice expressing human P450 aromatase. Endocrinology 143 4074-4083. (doi:10.1210/en.2002-220181)

Liu YX \& Hsueh AJ 1986 Synergism between granulosa and thecainterstitial cells in estrogen biosynthesis by gonadotropin-treated rat ovaries: studies on the two-cell, two-gonadotropin hypothesis using steroid antisera. Biology of Reproduction 35 27-36. (doi:10.1095/ biolreprod35.1.27)

Lonning PE, Haynes BP, Straume AH, Dunbier A, Helle H, Knappskog S \& Dowsett M 2011 Exploring breast cancer estrogen disposition: the basis for endocrine manipulation. Clinical Cancer Research 17 4948-4958. (doi:10.1158/1078-0432.CCR-11-0043)

Lubahn DB, Moyer JS, Golding TS, Couse JF, Korach KS \& Smithies O 1993 Alteration of reproductive function but not prenatal sexual development after insertional disruption of the mouse estrogen receptor gene. PNAS 90 11162-11166. (doi:10.1073/ pnas.90.23.11162)

MacDonald PC, Grodin JM \& Siiteri PK 1968 The utilization of plasma androstenedione for estrone production in women. In Progress in Endocrinology, Proceedings of the Third International Congress of Endocrinology, 30 June-5 July 1968, Mexico, Excerpta Medica International Congress Series No. 184, pp 770-776. Eds C Gual \& FJG Ebling. Amsterdam, The Netherlands: Excerpta Medica Foundation.

Meng L, Zhou J, Sasano H, Suzuki T, Zeitoun KM \& Bulun SE 2001 Tumor necrosis factor alpha and interleukin 11 secreted by malignant breast epithelial cells inhibit adipocyte differentiation by selectively downregulating CCAAT/enhancer binding protein alpha and peroxisome proliferator-activated receptor gamma: mechanism of desmoplastic reaction. Cancer Research 61 2250-2255. http://jme.endocrinology-journals.org

DOI: 10.1530/JME-15-0310
() 2016 Society for Endocrinology Printed in Great Britain
Published by Bioscientifica Ltd 
Morice P, Leary A, Creutzberg C, Abu-Rustum N \& Darai E 2016 Endometrial cancer. Lancet 387 1094-1108. (doi:10.1016/S01406736(15)00130-0)

Morimoto LM, White E, Chen Z, Chlebowski RT, Hays J, Kuller L, Lopez AM, Manson J, Margolis KL, Muti PC, et al. 2002 Obesity, body size, and risk of postmenopausal breast cancer: the Women's Health Initiative (United States). Cancer Causes Control 13 741-751. (doi:10.1023/A:1020239211145)

Nagasako S, Asanuma N \& Nagata Y 1988 [Plasma concentration of estrogens and androgens in postmenopausal women with or without endometrial cancer]. Nihon Sanka Fujinka Gakkai Zasshi 40 707-713.

Nakamura T, Imai Y, Matsumoto T, Sato S, Takeuchi K, Igarashi K, Harada Y, Azuma Y, Krust A, Yamamoto Y, et al. 2007 Estrogen prevents bone loss via estrogen receptor alpha and induction of Fas ligand in osteoclasts. Cell 130 811-823. (doi:10.1016/j.cell.2007.07.025)

Noble LS, Simpson ER, Johns A \& Bulun SE 1996 Aromatase expression in endometriosis. Journal of Clinical Endocrinology and Metabolism $\mathbf{8 1}$ 174-179.

O'Lone R, Knorr K, Jaffe IZ, Schaffer ME, Martini PG, Karas RH, Bienkowska J, Mendelsohn ME \& Hansen U 2007 Estrogen receptors alpha and beta mediate distinct pathways of vascular gene expression, including genes involved in mitochondrial electron transport and generation of reactive oxygen species. Molecular Endocrinology 21 1281-1296. (doi:10.1210/me.2006-0497)

Perou CM, Sorlie T, Eisen MB, van de Rijn M, Jeffrey SS, Rees CA, Pollack JR, Ross DT, Johnsen H, Akslen LA, et al. 2000 Molecular portraits of human breast tumours. Nature 406 747-752. (doi:10.1038/35021093)

Potischman N, Hoover RN, Brinton LA, Siiteri P, Dorgan JF, Swanson CA, Berman ML, Mortel R, Twiggs LB, Barrett RJ, et al. 1996 Case-control study of endogenous steroid hormones and endometrial cancer. Journal of National Cancer Institute 88 1127-1135. (doi:10.1093/ jnci/88.16.1127)

Price T, Aitken J, Head J, Mahendroo M, Means G \& Simpson E 1992 Determination of aromatase cytochrome P450 messenger ribonucleic acid in human breast tissue by competitive polymerase chain reaction amplification. Journal of Clinical Endocrinology and Metabolism 74 1247-1252.

Rizner TL 2013 Estrogen biosynthesis, phase I and phase II metabolism, and action in endometrial cancer. Molecular and Cellular Endocrinology 381 124-139. (doi:10.1016/j.mce.2013.07.026)

Rossouw JE, Anderson GL, Prentice RL, LaCroix AZ, Kooperberg C, Stefanick ML, Jackson RD, Beresford SA, Howard BV, Johnson KC, et al. 2002 Risks and benefits of estrogen plus progestin in healthy postmenopausal women: principal results from the Women's Health Initiative randomized controlled trial. JAMA 288 321-333.

Roy D \& Liehr JG 1999 Estrogen, DNA damage and mutations. Mutations Research 424 107-115. (doi:10.1016/S0027-5107(99)00012-3)

Santen RJ 1981 Suppression of estrogens with aminoglutethimide and hydrocortisone (medical adrenalectomy) as treatment of advanced breast carcinoma: a review. Breast Cancer Research Treatment 1 183-202. (doi:10.1007/BF01806259)

Santen RJ, Yue W \& Wang JP 2015 Estrogen metabolites and breast cancer. Steroids 99 61-66. (doi:10.1016/j.steroids.2014.08.003)

Sebastian S \& Bulun SE 2001 A highly complex organization of the regulatory region of the human CYP19 (aromatase) gene revealed by the Human Genome Project. Journal of Clinical Endocrinology and Metabolism 86 4600-4602. (doi:10.1210/jcem.86.10.7947)

Sebastian S, Takayama K, Shozu M \& Bulun SE 2002 Cloning and characterization of a novel endothelial promoter of the human CYP19 (aromatase P450) gene that is up-regulated in breast cancer tissue. Molecular Endocrinology 16 2243-2254. (doi:10.1210/me.2002-0123)

Sherman ME, Sturgeon S, Brinton LA, Potischman N, Kurman RJ, Berman ML, Mortel R, Twiggs LB, Barrett RJ \& Wilbanks GD 1997 Risk factors and hormone levels in patients with serous and endometrioid uterine carcinomas. Modern Pathology 10 963-968.
Shibutani S, Ravindernath A, Suzuki N, Terashima I, Sugarman SM, Grollman AP \& Pearl ML 2000 Identification of tamoxifen-DNA adducts in the endometrium of women treated with tamoxifen. Carcinogenesis 21 1461-1467. (doi:10.1093/carcin/21.8.1461)

Shozu M, Sebastian S, Takayama K, Hsu WT, Schultz RA, Neely K, Bryant M \& Bulun SE 2003 Estrogen excess associated with novel gain-of-function mutations affecting the aromatase gene. New England Journal of Medicine 348 1855-1865. (doi:10.1056/NEJMoa021559)

Siiteri PK 1978 Steroid hormones and endometrial cancer. Cancer Research 38 4360-4366.

Simpson ER 2003 Sources of estrogen and their importance. Journal of Steroid Biochemistry and Molecular Biology 86 225-230. (doi:10.1016/ S0960-0760(03)00360-1)

Simpson E \& Santen RJ 2015 Celebrating 75 years of oestradiol. Journal of Molecular Endocrinology 55 T1-T20. (doi:10.1530/JME-15-0128)

Simpson ER, Mahendroo MS, Means GD, Kilgore MW, Hinshelwood MM, Graham-Lorence S, Amarneh B, Ito Y, Fisher CR, Michael MD, et al. 1994 Aromatase cytochrome P450, the enzyme responsible for estrogen biosynthesis. Endocrine Reviews 15 342-355.

Sofi M, Young MJ, Papamakarios T, Simpson ER \& Clyne CD 2003 Role of CRE-binding protein (CREB) in aromatase expression in breast adipose. Breast Cancer Research Treatment 79 399-407. (doi:10.102 3/A:1024038632570)

Suzuki T, Miki Y, Nakamura Y, Moriya T, Ito K, Ohuchi N \& Sasano H 2005 Sex steroid-producing enzymes in human breast cancer. Endocrine Related Cancer 12 701-720. (doi:10.1677/erc.1.00834)

Swerdlow AJ, Jones ME \& British Tamoxifen Second Cancer Study G 2005 Tamoxifen treatment for breast cancer and risk of endometrial cancer: a case-control study. Journal of National Cancer Institute $\mathbf{9 7}$ 375-384.

Tekmal RR, Ramachandra N, Gubba S, Durgam VR, Mantione J, Toda K, Shizuta Y \& Dillehay DL 1996 Overexpression of int-5/aromatase in mammary glands of transgenic mice results in the induction of hyperplasia and nuclear abnormalities. Cancer Research 56 3180-3185.

Tong MH, Jiang H, Liu P, Lawson JA, Brass LF \& Song WC 2005 Spontaneous fetal loss caused by placental thrombosis in estrogen sulfotransferase-deficient mice. Nature Medicine 11 153-159. (doi:10.1038/nm1184)

Utsumi T, Harada N, Maruta M \& Takagi Y 1996 Presence of alternatively spliced transcripts of aromatase gene in human breast cancer. Journal of Clinical Endocrinology and Metabolism $\mathbf{8 1}$ 2344-2349.

Watanabe K, Sasano H, Harada N, Ozaki M, Niikura H, Sato S \& Yajima A 1995 Aromatase in human endometrial carcinoma and hyperplasia. Immunohistochemical, in situ hybridization, and biochemical studies. American Journal of Pathology 146 491-500.

White KK, Park SY, Kolonel LN, Henderson BE \& Wilkens LR 2012 Body size and breast cancer risk: the multiethnic cohort. International Journal of Cancer 131 E705-E716. (doi:10.1002/ijc.27373)

Yada H, Hosokawa K, Tajima K, Hasegawa Y \& Kotsuji F 1999 Role of ovarian theca and granulosa cell interaction in hormone productionand cell growth during the bovine follicular maturation process. Biology of Reproduction 61 1480-1486. (doi:10.1095/biolreprod61.6.1480)

Yamamoto T, Kitawaki J, Urabe M, Honjo H, Tamura T, Noguchi T, Okada H, Sasaki H, Tada A, Terashima Y, et al. 1993 Estrogen productivity of endometrium and endometrial cancer tissue: influence of aromatase on proliferation of endometrial cancer cells. Journal of Steroid Biochemistry and Molecular Biology 44 463-468. (doi:10.1016/0960-0760(93)90251-Q)

Zhao Y, Mendelson CR \& Simpson ER 1995a Characterization of the sequences of the human CYP19 (aromatase) gene that mediate regulation by glucocorticoids in adipose stromal cells and fetal hepatocytes. Molecular Endocrinology 9 340-349.

Zhao Y, Nichols JE, Bulun SE, Mendelson CR \& Simpson ER $1995 b$ Aromatase P450 gene expression in human adipose tissue. Role of a

Published by Bioscientifica Ltd. 
Jak/STAT pathway in regulation of the adipose-specific promoter. Journal of Biological Chemistry 270 16449-16457.

Zhao Y, Agarwal VR, Mendelson CR \& Simpson ER 1996a Estrogen biosynthesis proximal to a breast tumor is stimulated by PGE2 via cyclic AMP, leading to activation of promoter II of the CYP19 (aromatase) gene. Endocrinology 137 5739-5742.

Zhao Y, Nichols JE, Valdez R, Mendelson CR \& Simpson ER $1996 b$ Tumor necrosis factor-alpha stimulates aromatase gene expression in human adipose stromal cells through use of an activating protein-1 binding site upstream of promoter 1.4. Molecular Endocrinology 10 1350-1357.

Zhao H, Innes J, Brooks DC, Reierstad S, Yilmaz MB, Lin Z \& Bulun SE 2009 A novel promoter controls Cyp19a1 gene expression in mouse adipose tissue. Reproductive Biology and Endocrinology 737. (doi:10.1186/1477-7827-7-37)

Zhao H, Pearson EK, Brooks DC, Coon JS IV, Chen D, Demura M, Zhang M, Clevenger CV, Xu X, Veenstra TD, et al. 2012 A humanized pattern of aromatase expression is associated with mammary hyperplasia in mice. Endocrinology 153 2701-2713. (doi:10.1210/en.2011-1761)

Zhou D \& Chen S 1999 Identification and characterization of a cAMPresponsive element in the region upstream from promoter 1.3 of the human aromatase gene. Archives of Biochemistry and Biophysics 371 179190. (doi:10.1006/abbi.1999.1454)

Zhou C, Zhou D, Esteban J, Murai J, Siiteri PK, Wilczynski S \& Chen S 1996 Aromatase gene expression and its exon I usage in human breast tumors. Detection of aromatase messenger RNA by reverse transcription-polymerase chain reaction. Journal of Steroid Biochemistry and Molecular Biology 59 163-171. (doi:10.1016/S0960-0760(96)00100-8)

Zhou D, Zhou C \& Chen S 1997 Gene regulation studies of aromatase expression in breast cancer and adipose stromal cells. Journal of Steroid Biochemistry and Molecular Biology 61 273-280. (doi:10.1016/ S0960-0760(97)80023-4)

Zhou J, Gurates B, Yang S, Sebastian S \& Bulun SE 2001 Malignant breast epithelial cells stimulate aromatase expression via promoter II in human adipose fibroblasts: an epithelial-stromal interaction in breast tumors mediated by CCAAT/enhancer binding protein beta. Cancer Research 61 2328-2334.

Ziegler RG, Hoover RN, Nomura AM, West DW, Wu AH, Pike MC, Lake AJ, Horn-Ross PL, Kolonel LN, Siiteri PK, et al. 1996 Relative weight, weight change, height, and breast cancer risk in AsianAmerican women. Journal of National Cancer Institute 88 650-660. (doi:10.1093/jnci/88.10.650)

Received in final form 5 April 2016

Accepted 11 April 2016

Accepted Preprint published online 11 April 2016
(C) 2016 Society for Endocrinology Printed in Great Britain
Published by Bioscientifica Ltd 